\title{
Nematode Parasites of Rockfish (Sebastes spp.) and Cod (Gadus spp.) from Waters near Kodiak Island Alaska, USA
}

\author{
Mehmet Cemal Oğuz ${ }^{1}$, Andrea McRae Campbell ${ }^{2}$, Samuel P. Bennett ${ }^{2}$ and Mark C. Belk ${ }^{2, *(D)}$ \\ 1 Vocational School of Health Services, Mardin Artuklu University, Mardin 47200, Turkey; \\ mcoguz@artuklu.edu.tr \\ 2 Department of Biology, Brigham Young University, Provo, UT 84602, USA; \\ andreaemcrae@gmail.com (A.M.C.); sambennettslc@gmail.com (S.P.B.) \\ * Correspondence: mark belk@byu.edu; Tel.: +1-801-422-4154
}

Citation: Oğuz, M.C.; Campbell, A.M.; Bennett, S.P.; Belk, M.C. Nematode Parasites of Rockfish (Sebastes spp.) and Cod (Gadus spp.) from Waters near Kodiak Island Alaska, USA. Diversity 2021, 13, 436. https://doi.org/10.3390/d13090436

Academic Editor: Bert W. Hoeksema

Received: 30 April 2021

Accepted: 8 September 2021

Published: 10 September 2021

Publisher's Note: MDPI stays neutral with regard to jurisdictional claims in published maps and institutional affiliations.

Copyright: (C) 2021 by the authors. Licensee MDPI, Basel, Switzerland. This article is an open access article distributed under the terms and conditions of the Creative Commons Attribution (CC BY) license (https:// creativecommons.org/licenses/by/ $4.0 /)$

\begin{abstract}
Distribution and abundance of common parasitic nematodes in marine fishes is not well documented in many geographic regions. Understanding the influence of large-scale environmental changes on infection rates of fish by nematodes requires quantitative assessments of parasite abundance for multiple host species. We collected samples of two species of cod and eight species of rockfish (total of 232 specimens) from waters near Kodiak Island, Alaska, USA during Spring and Summer of 2015, and dissected and recorded all internal nematode parasites. We quantified the prevalence and intensity of nematode parasites in the ten host species, and tested for differences in prevalence among host species. We found three species of nematode: Anisakis simplex, sensu lato (Van Thiel), Pseudoterranova decipiens, sensu lato (Krabbe), and Hysterothylacium sp. (Ward and Magath). Eighty-two percent of the examined fish were infected with at least one parasitic nematode. The overall prevalence of $P$. decipiens, A. simplex, and Hysterothylacium sp. was $56 \%$, 62\%, and 2\%, respectively. Anisakis simplex and $P$. decipiens were abundant and present in all ten species of host fish examined, whereas Hysterothylacium sp. was rare and found in only five of the host fish species. Prevalence and mean intensity of $P$. decipiens and $A$. simplex varied across the ten host species, and the number of parasites varied substantially among individual hosts within host species. The mean intensity of $P$. terranova and $A$. simplex in our study was substantially higher than the mean intensity for these same species from multiple other locations in a recent meta-analysis. This study provides a baseline of nematode parasite abundance in long-lived fish in waters near Kodiak Island, AK, and fills an important gap in our quantitative understanding of patterns of occurrence and abundance of these common and widespread parasites of marine fish.
\end{abstract}

Keywords: Anisakidae; Chromadorea; Southwest Alaska; Gadus; Sebastes

\section{Introduction}

Documenting environmental change, and consequent change in the distribution of organisms, has become increasingly important for understanding the ecological and evolutionary responses of organisms over time [1]. Several examples of change in distribution, abundance, and diversity of species have been observed because of good baseline data available from previous research [1-3]. However, detecting such changes without baseline data is difficult, and quantifying the effects of change is impossible without previously collected quantitative data [4]. Although some biological systems have been well studied, there are still many geographic locations and taxonomic groups of organisms where the distribution, abundance and occurrence are poorly documented [1,4]. There is a pressing need for increased quantitative data collection on parasite distribution to understand spatial and temporal trends.

Nematodes (Phylum Chromadorea) can occur in high intensities and have high infection rates in many species of fish $[1,5]$. Endoparasitic nematodes of marine fish impact fish health, the quality of fish for human consumption, and human health $[1,6]$. Although 
some host species of marine nematodes have been well studied (i.e., Oncorhynchus spp., Hippoglossus stenolepis; $[6,7])$, the distribution and abundance of nematodes in other known hosts have received less attention. Pacific rockfish, in particular, represent an important fishery resource in the northeast Pacific [8,9]. Although there are many studies that have specifically focused on rockfish [8], few quantitative studies of nematode parasites of rockfish $[10,11]$ and cod are available in recent times and from one geographic location, and none are available from the southwestern Gulf of Alaska near Kodiak Island [1]. As environments change, parasite distribution or abundances will likely also change. To understand the influence of large-scale environmental changes on infection rates of fish by nematodes, it is important to perform quantitative assessments of parasite abundance for multiple host species in many locations [1].

In addition to determining the effects of environmental variation, the resolution of ecological and evolutionary patterns of parasites and their hosts is dependent on quantitative and comparable data on parasites and their hosts in varying geographical areas [4,12]. At a minimum, researchers should report prevalence and intensity (along with some measure of variance within host species), and it is recommended that the distribution of intensities be included because often the distributions of parasites are clumped within a few individuals [13]. Availability of these quantitative measures from multiple species and geographic regions allows tests of ecological and evolutionary hypotheses on topics such as niche partitioning, processes that influence community composition, and diversity related to host traits [12]. However, studies that compare these quantitative measures of multiple parasites among multiple host species are rare.

To provide baseline data and to document current conditions in this geographic area, we conducted a survey of nematode prevalence and intensity in rockfish and cod in waters near Kodiak Island, Alaska, USA. We quantified nematode prevalence and intensity, and compared these among multiple species of fish hosts. We tested for differences in prevalence among species of nematodes and among host species and we characterized the distribution of nematode parasites within host species. Together, these data and comparisons provide valuable baseline data for this poorly documented area and host species.

\section{Materials and Methods}

Kodiak Island is a large island off the coast of southeastern Alaska, USA. The island is home to the largest fishing port in Alaska, and is one of the largest fishery ports in the USA. We examined a total of 232 fish of ten species as follows: Pacific ocean perch, Sebastes alutus (Gilbert; $n=20$; May 2015); silvergray rockfish, S. brevispinis (Bean; $n=20$; June 2015); dark rockfish, S. ciliatus (Tiliesius; $n=49$; May, August, September 2015); black rockfish, S. melanops (Girard; $n=23$; June 2015); northern rockfish, S. polyspinis (Taranets and Mosiev; $n=20$; May, June 2015); redstripe rockfish, S. proriger (Jordan and Gilbert; $n=20$; June, July 2015); yelloweye rockfish, S. ruberrimus (Cramer; $n=20$; June, July 2015); harlequin rockfish, S. variegatus (Quast; $n=20$; June 2015); Pacific cod, Gadus macrocephalus (Tilesius; $n=20$; September 2015); and Alaska pollock, Gadus chalcogrammus (Pallas; $n=20$; September 2015). We purchased specimens of nine of the ten species from the local fish processing facility of Trident Seafoods Corporation on Kodiak Island, and we captured specimens of $S$. melanops by hook and line from a charter boat. The samples we acquired from Trident Seafoods were caught by net trawlers as part of commercial fishing operations in the area surrounding Kodiak Island (Figure 1). Gadus chalcogramus was collected in the Shelikhov Strait west of Kodiak Island in relatively shallow depths $(<200 \mathrm{~m})$, and Sebastes melanops was collected nearshore on the east side of Kodiak Island in relatively shallow depths $(<200 \mathrm{~m})$. All other host fish species were collected further east of Kodiak Island at much greater depths (>>200 m). We purchased freshly killed specimens immediately upon their arrival at the fish processing facility in which parasites were still alive and active. We obtained all samples between May and October of 2015, and fish dissections, parasite collection, and preservation were performed at the Kodiak Seafood and Marine Science Center on Near Island, Alaska, USA. 


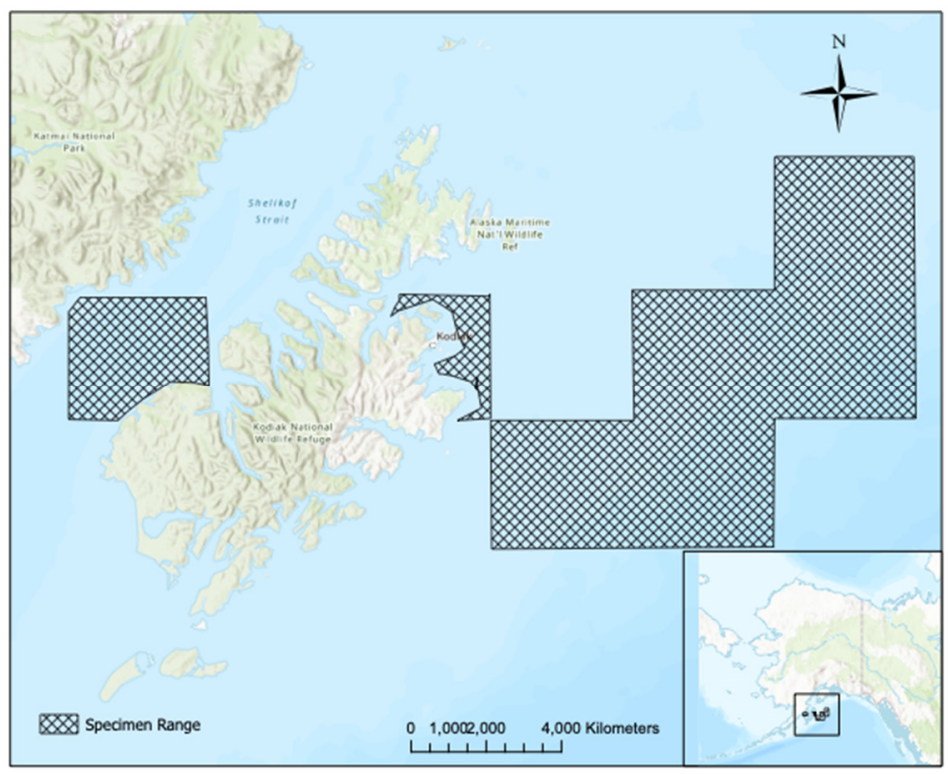

Figure 1. Map of collection location for all host fish species. Hatched area represents area sampled for fish collections near Kodiak Island, Alaska, USA.

To facilitate the detection of parasites, we carefully searched all internal organs in the body cavity according to standard dissection methods (14). Briefly, we split the digestive tract along its entire length and searched both the internal and external surfaces. We cut all solid organs, such as the liver and gonads, into small pieces and examined each piece under a Nikon MK II Microscope. We then filleted the flesh off both sides and visually searched the muscle for parasites. We received the S. ruberrimus samples after they had been filleted, so only the internal organs were available for inspection. We found the vast majority of nematodes within organ structures and only rarely in the muscle tissue, and we assume that the locations of nematodes found within S. ruberrimus are consistent with this trend. As nematodes were detected, we cleared and preserved them according to methods outlined in [14]. Briefly, we cleared specimens in a 1:1 solution of EtOH and glycerol. As the ethanol evaporated, we gradually added glycerol to prevent the specimens from collapsing. After they were cleared, we stored them in ethanol. Identification and description of nematodes was based on [15,16] and http:/ / www.marinespecies.org/ (accessed on 16 June 2018). Specifically, we used characteristics of the caecum, general size, and morphology of the anterior region to differentiate among the three observed species of nematodes $[15,16]$. We did not use molecular methods to differentiate nematode species; however, differentiation of these species is generally clear based on the characters reviewed $[15,16]$ and seen in Figure 2. We acknowledge that there may be hidden diversity that we were unable to discern given our reliance on morphology for identification, so we indicate this potential uncertainty by the use of the term sensu lato after species names. We calculated quantitative descriptors of the parasite populations according to [12,13], and for mean intensity we included confidence intervals of the mean. 


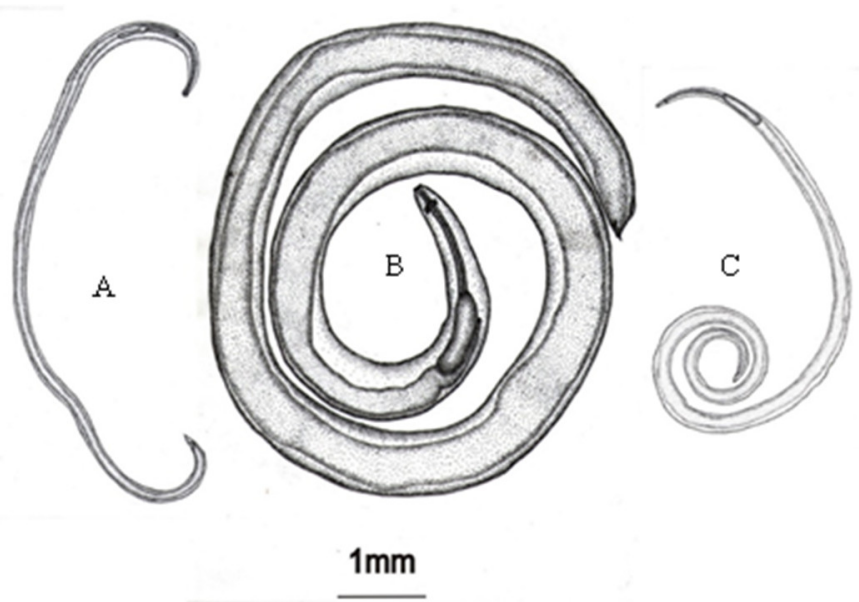

Figure 2. Line drawings of A: Hysterothylacium sp.; B: Pseudoterranova decipiens; C: Anisakis simplex showing differences in size and internal structure. Drawings were made from specimens collected for this study.

We performed chi-square tests to determine differences in prevalence among host species and among parasite species. To better understand how the number of parasites varies within and among host species, and to address the possibility that parasites exhibit a clumped distribution of individuals within a few individual hosts, we characterized the frequency distribution of parasites within host species [13]. Specifically, to determine if distributions were clumped, we calculated the percentage of the total number of a given parasite found within a host species that was contained in the most highly infected individual host. (We define "clumping" as a distribution of parasites in which a few fish have most of the parasites.) Obviously, this clumping index is not very useful when the total number of parasites is low.

\section{Results}

We found three species of parasitic nematodes (Figure 2) in 232 potential host fish, with parasite totals as follows: 440 Pseudoterranova decipiens sensu lato (hereafter P. decipiens), 753 Anisakis simplex sensu lato (hereafter $A$. simplex), and 5 Hysterothylacium sp. The majority of individual nematodes were larvae, but some were adult. Eighty-two percent of the inspected fish were infected with at least one parasitic nematode. Anisakis simplex and $P$. decipiens were found in at least some individuals of all ten species of fish. Five of the fish species (G. macrocephalus, S. brevispinis, S. ciliatus, S. melanops, and S. proriger) had one individual each that was infected with one individual Hysterothylacium sp. (Table 1).

Prevalence and mean intensity varied substantially among host species and among parasite species (Table 1). Prevalence of P. decipiens ranged from $15 \%$ in S. ruberrimus to $90 \%$ in G. macrocephalus with a mean of $55.6 \%$ across all host species. Gadus macrocephalus had a significantly higher prevalence than the mean, whereas S. ruberrimus had a significantly lower prevalence than the mean, and the other eight species we examined were no different in prevalence from the overall mean (Table 1). Prevalence of $A$. simplex ranged from $35 \%$ in S. proriger to $95 \%$ in $S$. variegatus with a mean of $61.6 \%$ across all host species. Despite this wide range in prevalence of $A$. simplex, none of the ten host species exhibited a significant departure from the overall mean (Table 1). Mean intensity for $P$. decipiens ranged from 1.0 in S. ruberrimus to 6.6 in G. macrocephalus with a mean of 3.41 across all host species. Mean intensity for A. simplex ranged from 2.36 in G. macrocephalus to 10.5 in S. ruberrimus with a mean of 5.27 across all host species. 
Table 1. Quantitative descriptors of three species of parasitic nematodes in ten species of fish from waters near Kodiak Island, Alaska, USA. Host species name is followed by the sample size for each host species and the range of total length (TL) and mean total length of hosts (ML); TPN: total parasite number; $\mathrm{P} \%$ : prevalence as a percentage; MI: mean intensity (confidence interval). Prevalence departures from the overall mean were tested by a one-sample chi-squared test and the resulting $p$-values are listed below the percentage prevalence value. Significant values $(p<0.05)$ are bolded.

\begin{tabular}{|c|c|c|c|c|c|}
\hline Host Species & & Pseudoterranova Decipiens & Anasakis Simplex & Hysterothylacium sp. & All Nematodes \\
\hline \multirow{3}{*}{$\begin{array}{c}\text { Gadus chalcogrammus } \\
\boldsymbol{n}=\mathbf{2 0} \\
\text { TL: } 315-390 \mathrm{~mm} \\
\text { ML: } 356 \mathrm{~mm}\end{array}$} & TPN & 22 & 51 & - & 73 \\
\hline & $\mathrm{P} \%$ & $\begin{array}{c}65 \\
p=0.57\end{array}$ & $\begin{array}{c}80 \\
p=0.29\end{array}$ & - & $\begin{array}{c}90 \\
p=0.69\end{array}$ \\
\hline & MI & $1.7(1.12-2.26)$ & $3.19(2.14-4.24)$ & - & $4.1(2.75-5.35)$ \\
\hline \multirow{3}{*}{$\begin{array}{c}\text { Gadus macrocephalus } \\
n=\mathbf{2 0} \\
\text { TL: } 400-485 \mathrm{~mm} \\
\text { ML: } 441 \mathrm{~mm}\end{array}$} & TPN & 119 & 26 & 1 & 146 \\
\hline & $\mathrm{P} \%$ & $\begin{array}{c}90 \\
p=\mathbf{0 . 0 4}\end{array}$ & $\begin{array}{c}55 \\
p=0.71\end{array}$ & 5 & $\begin{array}{c}90 \\
p=0.69\end{array}$ \\
\hline & MI & $6.6(3.89-9.33)$ & $2.36(1.04-3.68)$ & 1.0 & $8.1(4.93-11.18)$ \\
\hline \multirow{3}{*}{$\begin{array}{c}\text { Sebastes alutus } \\
\boldsymbol{n}=\mathbf{2 0} \\
\text { TL: } 380-435 \mathrm{~mm} \\
\text { ML: } 415 \mathrm{~mm}\end{array}$} & TPN & 47 & 96 & - & 143 \\
\hline & $\mathrm{P} \%$ & $\begin{array}{c}65 \\
p=0.57\end{array}$ & $\begin{array}{c}85 \\
p=0.18\end{array}$ & - & $\begin{array}{c}95 \\
p=0.52\end{array}$ \\
\hline & MI & $3.6(2.39-4.84)$ & $5.65(2.96-8.33)$ & - & $7.5(4.95-10.1)$ \\
\hline \multirow{3}{*}{$\begin{array}{c}\text { Sebastes brevispinis } \\
\boldsymbol{n}=\mathbf{2 0} \\
\text { TL: } 445-625 \mathrm{~mm} \\
\text { ML: } 516 \mathrm{~mm}\end{array}$} & TPN & 21 & 29 & 1 & 51 \\
\hline & $\mathrm{P} \%$ & $\begin{array}{c}35 \\
p=0.22\end{array}$ & $\begin{array}{c}50 \\
p=0.51\end{array}$ & 5 & $\begin{array}{c}70 \\
0.56\end{array}$ \\
\hline & MI & $3.0(0.86-5.14)$ & $2.9(0.46-5.34)$ & 1.0 & $3.6(1.11-6.03)$ \\
\hline \multirow{3}{*}{$\begin{array}{c}\text { Sebastes ciliatus } \\
n=49 \\
\text { TL: } 295-500 \mathrm{~mm} \\
\text { ML: } 417 \mathrm{~mm}\end{array}$} & TPN & 91 & 71 & 1 & 163 \\
\hline & $\mathrm{P} \%$ & $\begin{array}{c}65.3 \\
p=0.36\end{array}$ & $\begin{array}{c}55.1 \\
p=0.56\end{array}$ & 2 & $\begin{array}{c}83.7 \\
p=0.89\end{array}$ \\
\hline & MI & $2.84(1.80-3.89)$ & $2.63(1.62-3.64)$ & 1.0 & $3.97(2.79-5.11)$ \\
\hline \multirow{3}{*}{$\begin{array}{l}\text { Sebastes melanops } \\
\qquad n=23 \\
\text { TL: } 420-540 \mathrm{~mm} \\
\text { ML: } 481 \mathrm{~mm}\end{array}$} & TPN & 28 & 95 & 1 & 124 \\
\hline & $\mathrm{P} \%$ & $\begin{array}{c}47.8 \\
p=0.62\end{array}$ & $\begin{array}{c}43.5 \\
p=0.27\end{array}$ & 4.3 & $\begin{array}{c}69.6 \\
p=0.51\end{array}$ \\
\hline & MI & $2.55(1.26-3.83)$ & $9.5(0.65-18.35)$ & 1.0 & 7.75 (1.91-13.47) \\
\hline \multirow{3}{*}{$\begin{array}{c}\text { Sebastes polyspinis } \\
n=\mathbf{2 0} \\
\text { TL: } 345-430 \mathrm{~mm} \\
\text { ML: } 395 \mathrm{~mm}\end{array}$} & TPN & 48 & 78 & - & 126 \\
\hline & $\mathrm{P} \%$ & $\begin{array}{c}65 \\
p=0.57\end{array}$ & $\begin{array}{c}65 \\
p=0.85\end{array}$ & - & $\begin{array}{c}90 \\
p=0.69\end{array}$ \\
\hline & MI & $3.7(1.94-5.44)$ & $6.0(1.50-10.50)$ & - & $7.0(3.61-10.39)$ \\
\hline \multirow{3}{*}{$\begin{array}{c}\text { Sebastes proriger } \\
\boldsymbol{n}=\mathbf{2 0} \\
\text { TL: } 345-450 \mathrm{~mm} \\
\text { ML: } 368 \mathrm{~mm}\end{array}$} & TPN & 20 & 28 & 1 & 49 \\
\hline & $\mathrm{P} \%$ & $\begin{array}{c}50 \\
p=0.74\end{array}$ & $\begin{array}{c}35 \\
p=0.13\end{array}$ & 5 & $\begin{array}{c}70 \\
p=0.56\end{array}$ \\
\hline & MI & $2.0(1.11-2.89)$ & $4.0(1.33-6.67)$ & 1.0 & $3.5(1.39-6.0)$ \\
\hline \multirow{3}{*}{$\begin{array}{c}\text { Sebastes ruberrimus } \\
n=\mathbf{2 0} \\
\text { TL: } 430-760 \mathrm{~mm} \\
\text { ML: } 631 \mathrm{~mm}\end{array}$} & TPN & 3 & 137 & - & 140 \\
\hline & $\mathrm{P} \%$ & $\begin{array}{c}15 \\
p=\mathbf{0 . 0 1 5}\end{array}$ & $\begin{array}{c}65 \\
p=0.85\end{array}$ & - & $\begin{array}{c}65 \\
p=0.4\end{array}$ \\
\hline & MI & 1.0 (NA) & $10.5(-7.37-28.44)$ & - & $10.8(-7.27-28.8)$ \\
\hline \multirow{3}{*}{$\begin{array}{c}\text { Sebastes variegatus } \\
\boldsymbol{n}=\mathbf{2 0} \\
\text { TL: } 329-400 \mathrm{~mm} \\
\text { ML: } 361 \mathrm{~mm}\end{array}$} & TPN & 41 & 142 & - & 183 \\
\hline & $\mathrm{P} \%$ & $\begin{array}{c}45 \\
p=0.52\end{array}$ & $\begin{array}{c}95 \\
p=0.057\end{array}$ & - & $\begin{array}{c}95 \\
p=0.52\end{array}$ \\
\hline & MI & $4.55(2.12-6.99)$ & $7.47(5.05-9.90)$ & - & $9.6(6.46-12.80)$ \\
\hline \multirow{3}{*}{$\begin{array}{c}\text { All fish } \\
n=\mathbf{2 3 2} \\
\text { TL: } 295-760 \mathrm{~mm} \\
\text { ML: } 436 \mathrm{~mm}\end{array}$} & TPN & 440 & 753 & 5 & 1198 \\
\hline & $\mathrm{P} \%$ & 55.6 & 61.6 & 2.2 & 81.9 \\
\hline & MI & $3.41(2.84-3.98)$ & $5.27(3.57-6.96)$ & 1.0 & $6.3(4.93-7.69)$ \\
\hline
\end{tabular}


The distribution of number of parasites within host species showed evidence for clumping in some species. In general, $P$. decipiens exhibited little evidence of clumping (only one host species), whereas A. simplex showed moderate clumping in S. brevispinis, $S$. melanops, S. polyspinis, and S. proriger (at least one third of the total number of A. simplex were found in one individual). Extreme clumping was evident in $S$. ruberrimus, where one individual contained 109 individual A. simplex, comprising $80 \%$ of the number found in all S. ruberrimus and over 10\% of the number found in all host species in this study (Table 2).

Table 2. Frequency distribution of the number of parasites per individual host species for ten host species of cod and rockfish and two species of nematode parasites collected in waters near Kodiak Island, Alaska, USA. The last column gives the percentage of the total number of parasites found in the most highly infected individual (for values $>1$ individual). Values that represent greater than one third of the total sample are bolded for emphasis. Only one individual of Hysterothylacium sp. was found in one individual of five host species, so data on this parasite are not included in the table.

\begin{tabular}{|c|c|c|c|c|c|c|}
\hline \multicolumn{7}{|c|}{ Number of Hosts with Given Number of Parasites } \\
\hline Host Species & Parasite Species & 1 & 2-5 (Max) & 6-10 (Max) & $11+($ Max) & $\%$ of Total in Highest Individual \\
\hline G. chalcogrammus & P. decipiens & 7 & $6(4)$ & - & - & 18 \\
\hline G. macrocephalus & P. decipiens & 4 & 5 & 5 & $4(17)$ & 14 \\
\hline S. alutus & P. decipiens & 2 & 8 & $3(7)$ & - & 15 \\
\hline S. brevispinis & P. decipiens & 1 & 5 & $1(8)$ & - & 38 \\
\hline S. ciliatus & P. decipiens & 15 & 12 & 3 & $2(12)$ & 13 \\
\hline S. melanops & P. decipiens & 5 & 5 & $1(7)$ & - & 25 \\
\hline S. polyspinis & P. decipiens & 4 & 6 & $3(10)$ & - & 21 \\
\hline S. proriger & P. decipiens & 5 & $5(4)$ & - & - & 20 \\
\hline S. ruberrimus & P. decipiens & 3 & - & - & - & - \\
\hline S. variegatus & P. decipiens & 2 & 3 & $4(8)$ & - & 20 \\
\hline G. chalcogrammus & A. simplex & 3 & 12 & $1(8)$ & - & 16 \\
\hline G. macrocephalus & A. simplex & 5 & 5 & $1(7)$ & - & 9 \\
\hline S. alutus & A. simplex & 3 & 9 & 1 & $4(18)$ & 19 \\
\hline S. brevispinis & A. simplex & 6 & 2 & 1 & $1(11)$ & 38 \\
\hline S. ciliatus & A. simplex & 13 & 12 & 1 & $1(12)$ & 17 \\
\hline S. melanops & A. simplex & 3 & 3 & 2 & $2(36)$ & 38 \\
\hline S. polyspinis & A. simplex & 1 & 8 & 2 & $2(26)$ & 33 \\
\hline S. proriger & A. simplex & 0 & 6 & $1(10)$ & - & 36 \\
\hline S. ruberrimus & A. simplex & 6 & 4 & 1 & $1(109)$ & 80 \\
\hline S. variegatus & A. simplex & 2 & 6 & 6 & $5(19)$ & 13 \\
\hline
\end{tabular}

\section{Discussion}

Overall, patterns of prevalence and intensity among the ten host species we studied are remarkably similar for the two common species of parasitic nematodes. About half of individuals of all host species were infected by $P$. decipiens or A. simplex. No host species exhibited $100 \%$ or $0 \%$ prevalence, and wide variation in the number of parasites among individuals within host species overwhelmed the variation in mean intensity among host species. This lack of extreme variation among host species suggests that host traits at the species level are unlikely to be influential in determining the prevalence of these two parasitic nematodes among these species of host fish. Rather, this pattern is consistent with the idea that differences among individual hosts, such as level of immune function or current physiological state, may determine the probability of becoming infected and the number of parasites in a given host $[17,18]$. For example, in our study, a few individual hosts had inordinately high numbers of parasites. The most extreme of these was one S. ruberrimus that contained 109 A simplex. The visceral organs of this individual fish looked pale and appeared to be deteriorating. We do not know if this individual was in 
poor condition and thus was more susceptible to parasitic infection or if the high level of infection by $A$. simplex was responsible for the poor condition.

All three species of parasitic nematodes that we observed in our study have previously been documented in multiple species of host fish in Alaskan waters. Anisakis simplex has been documented in G. chalcogrammus and in at least four other fish species in Alaskan coastal waters [19-29]. Pseudoterranova decipiens has been documented in nine species of fish in Alaskan waters [19-29]. Hysterothylacium sp. has been found in 19 fish species from Alaskan coastal waters [19-29]. Clearly, these parasitic nematodes are common in many species of host fish in this area; however, quantitative studies, such as ours, are lacking [1].

Rockfish (Sebastes spp.) sampled in this study can be divided into two groups based on feeding and habitat use-pelagic fish feeding mainly on zooplankton (i.e., krill, mysids, and amphipods) and small pelagic fish, and benthic fish feeding mainly on other fish [8]. A similar division is evident between the two species of cod; G. chalcogrammus is more pelagic and G. macrocephalus is more benthic. Of our eight species of rockfish, all but S. ruberrimus fit into the pelagic feeding group, whereas S. ruberrimus is benthic-oriented and feeds at a higher trophic level than the other species [8]. Gadus chalcogrammus differs slightly from G. macrocephalus in the prevalence and mean intensity of the two common nematode species, with P. decipiens being dominant in G. macrocephalus and A. simplex being dominant in G. chalcogrammus. Sebastes ruberrimus exhibits very low infection rates of P. decipiens, and except for one highly infected individual, low infection rates by $A$. simplex. It may be that parasite abundance or diversity in fish may be higher at shallower depths [30]. The pelagic-feeding rockfish can be divided into two groups based on the average depth they occupy. Three species (S. brevispinnis, S. ciliatus, and S. melanops) are typically found in shallower depths compared to the other four species (S. alutus, S. polyspinis, S. proriger, and $S$. variegatus) typically found deeper [8]. Based on the prevalence and mean intensity in Table 1, there is little difference in nematode abundances in deeper versus shallower species in this study.

All three species of parasitic nematodes reported in this study are trophically transmitted [31,32]. Fish serve as an intermediate, paratenic host for both P. decipiens [31] and A. simplex [32], and the final host is a marine mammal. Typically, these nematodes mature into adults in the marine mammal (although adult $P$. decipiens were observed in some host fish), and parasite eggs are shed along with feces of the host. Larval nematodes are consumed by crustaceans, which are consumed by fish or marine mammals, in turn [31,32], thus completing the life cycle. We do not have data available in this study to evaluate specific patterns in the life cycle (sensu [32]).

We were not able to use the digestion method [33] or incubation method [34] to discover larval nematodes. Abundances may have been even higher had we been able to do so. However, a recent meta-analysis that compared estimates of abundance through time from studies that used older methods (such as ours) for detecting nematodes to studies that used newer methods found that the patterns of abundance through time were not significantly affected by the method of detection used [1]. This meta-analysis suggests that our estimates of abundance are likely accurate despite our use of older methods. The mean intensities of $P$. terranova and A. simplex in our study were substantially higher than the mean intensity for these same species in a recent meta-analysis [1].

This recent meta-analysis of abundance of Anisakis spp. and Pseudoterranova spp. over the last 50 years revealed a substantial increase in Anisakis spp., but no change in abundance of Pseudoterranova spp. [1]. This telling analysis would not have been possible without quantitative studies of parasitic nematode abundance such as ours. The literature search for [1] revealed no quantitative data on parasitic nematodes of fish available for the southwestern Gulf of Alaska. The current study helps to fill this void such that future studies similar to [1] can be even more comprehensive in their scope. 
Author Contributions: Conceptualization, M.C.O. and M.C.B.; Data curation, A.M.C. and M.C.B.; Formal analysis, M.C.B. and A.M.C.; Funding acquisition, M.C.O. and M.C.B.; Investigation, M.C.O. and M.C.B.; Methodology, M.C.O. and M.C.B.; Project administration, M.C.O.; Resources, M.C.O. and M.C.B.; Supervision, M.C.O.; Visualization, M.C.O., A.M.C., S.P.B. and M.C.B.; Writing-original draft, M.C.O., M.C.B. and S.P.B.; Writing-review and editing, M.C.O., A.M.C., S.P.B. and M.C.B. All authors have read and agreed to the published version of the manuscript.

Funding: This research was funded by a grant from the Scientific Research Council of Turkey (TUBITAK, Grant \# B.14.2.TBT.0.06.01-219-115543), The APC was funded by Brigham Young University.

Institutional Review Board Statement: Ethical review and approval were waived for this study because all fish specimens were dead when we acquired them for the study.

Data Availability Statement: The data presented in this study are openly available from DRYAD (doi:10.5061/dryad.rbnzs7hc0).

Acknowledgments: We thank the Scientific Research Council of Turkey, Brigham Young University, Atatürk University, and the University of Alaska for their technical and logistic help. We thank the faculty of Kodiak Seafood and Marine Science Center for allowing us to use this facility for initial dissections of fish. We thank the Kodiak NOAA (National Oceanic and Atmospheric Administration), Alaska Fish and Game, and Trident Seafoods Corporation facility on Kodiak Island for cooperation and assistance during our study. We thank Yahya Tepe, Alexandria Hoth, Quentin Fong, Dennis Shiozawa, Keith Criddle, Paula Cullenberg, Brian Himelbloom, Julianne Kalman Passarelli, Julie Matweyou, Laurinda Kay, Robert Foy, Bill Donaldson, Christina Conrath, and Carrie Worton for assistance in data collection and comments on the manuscript. No endorsement is implied by being listed in acknowledgments.

Conflicts of Interest: The authors declare no conflict of interest.

\section{References}

1. Fiorenza, E.A.; Wendt, C.A.; Dobkowski, K.A.; King, T.L.; Pappaionou, M.; Rabinowitz, P.; Samhouri, J.F.; Wood, C.L. It's a wormy world: Meta-analysis reveals several decades of change in the global abundance of the parasitic nematodes Anisakis spp. and Pseudoterranova spp. in marine fishes and invertebrates. Glob. Chang. Biol. 2020, 26, 2854-2866. [CrossRef] [PubMed]

2. Basilio, A.; Searcy, S.; Thompson, A.R. Effects of the Blob on settlement of spotted sand bass, Paralabrax maculatofasciatus, to Mission Bay, San Diego, CA. PLoS ONE 2017, 12, e0188449. [CrossRef]

3. Du, X.; Peterson, W.T. Phytoplankton community structure in 2011-2013 compared to the extratropical warming event of 2014-2015. Geophys. Res. Lett. 2018, 45, 1534-1540. [CrossRef]

4. Poulin, R.; Moran, S. Parasite Biodiversity; Smithsonian Institution Scholarly Press: Washington, DC, USA, 2004.

5. Moravec, F. Nematode parasites of fishes: Recent advances and problems of their research. Parasitologia 2007, 49, 155-160.

6. Shamsi, S.; Chen, Y.C.; Poupa, A.; Ghadam, M.; Justine, J.L. Occurrence of anisakid parasites in marine fishes and whales off New Caledonia. Parasitol. Res. 2018, 117, 3195-3204. [CrossRef]

7. Han, H.J.; Seo, J.S.; Park, J.S.; Lee, H.L.; Seo, H.G.; Jung, S.H.; Kwon, S.R. First report of Clavinema mariae (Nematoda: Philometridae) in cultured rockfish, Sebastes schlegeli, in Cheonsuman (Bay), the Republic of Korea. Korean J. Parasitol. 2017, 55, $219-224$. [CrossRef]

8. Love, M.S.; Yoklavich, M.; Thorsteinson, L. The Rockfishes of the Northeast. Pacific; The University of California Press: Berkley, CA, USA, 2002.

9. Woodby, D.; Carlile, D.; Siddeek, S.; Funk, F.; Clark, J.H.; Hulbert, L. Commercial Fisheries of Alaska; Alaska Department of Fish and Game, Division of Commercial Fisheries: Juneau, AK, USA, 2005.

10. Sekerak, A.D.; Arai, H.P. Helminths of Sebastes alutus (Pisces: Teleostei) from Northeastern Pacific. Can. J. Zool. 1973, 1, 475-477. [CrossRef] [PubMed]

11. Sekerak, A.D.; Arai, H.P. Some metazoan parasites of rockfishes of the genus Sebastes from the Northeastern Pacific Ocean. Syesis 1977, 10, 139-144.

12. Bush, A.O.; Shostak, A.W.; Lotz, J.M. Parasitology meets ecology on its own term: Margolis et. al. revisited. J. Parasitol. 1997, 83, 575-583. [CrossRef]

13. Rózsa, L.; Reiczigel, J.; Majoros, G. Quantifying parasites in samples of hosts. J. Parasitol. 2000, 86, 228-232. [CrossRef]

14. Pritchard, M.H.; Kruse, G.O.W. The Collection and Preservation of Animal Parasites. Technical Bulletin No 1; University Of Nebraska Press: Lincoln, NE, USA; London, UK, 1982.

15. Skryabin, K.I. Key to Parasitic Nematodes; Amerind Publishing: New Delhi, India, 1984.

16. Arai, H.P.; Smith, J.W. Guide to the parasites of the fishes of Canada. Part V: Nematodes. Zootaxa 2016, 4185, 1-274. [CrossRef]

17. Schmid-Hempel, P. Evolutionary Parasitology: The Integrated Study of Infections, Immunology, Ecology, and Genetics; Oxford University Press: New York, NY, USA, 2011. 
18. Sitja-Bobadilla, A. Living off a fish: A trade-off between parasites and the immune system. Fish. Shellfish. Immunol. 2008, 25, 358-372. [CrossRef]

19. Moles, A.; Heifetz, J.; Love, D.C. Metazoan parasites as potential markers for selected Gulf Of Alaska rockfishes. Fish. Bull. 1998, 96, 912-916.

20. Urawa, S. Stock identification of chinook salmon (Oncorhynchus tshawytcha) in the north Pacific Ocean and Bering Sea by parasite tags. N. Pac. Anadr. Fish. Comm. Bull. 1998, 1, 199-204.

21. Arthur, J.R. A survey of the parasites of walleye pollock (Theragra chalcogramma) from the northeastern Pacific Ocean off Canada and a zoogeographical analysis of the parasite fauna of this fish throughout its range. Can. J. Zool. 1984, 62, 675-684. [CrossRef]

22. Mamaev, Y.L. Helminths of fish in the Bering Sea. In Parasitic Worms of Domestic and Wild Animals; Leonov, A.A., Mamaev, Y.L., Oshmarin, P.G., Eds.; Akademiya Nauk SSSR: Vladivostok, Russia, 1965; pp. 168-188.

23. Rausch, R.L.; Adams, A.M. Natural transfer of helminths of marine origin to freshwater fishes, with observations on the development of Diphyllobothrium alascense. J. Parasitol. 2000, 86, 319-327. [CrossRef]

24. Scheffer, V.B. Invertebrates and fishes collected in the Aleutians, 1936-1938. In Fauna of the Aleutian Islands and Alaska Peninsula; Murie, O.J., Ed.; U.S. Fish and Wildlife Service: Washington, DC, USA, 1959; Volume 61, pp. 365-406.

25. Arthur, J.R.; Arai, H.P. Studies on the parasites of Pacific herring (Clupea harengus pallasi Valenciennes): A preliminary evaluation of parasites as indicators of geographical origin for spawning herring. Can. J. Zool. 1980, 58, 521-527. [CrossRef]

26. Dunagan, T.T. Helminth parasites of Alaskan muskrats. Trans. Am. Microsc. Soc. 1957, 76, 318-320. [CrossRef]

27. Moles, A.; Heintz, R.A. Parasites of forage fishes in the vicinity of steller sea lion (Eumetopias jubatus) habitat in Alaska. J. Wildl. Dis. 2007, 43, 366-375. [CrossRef] [PubMed]

28. Pennell, D.A.; Becker, C.D.; Scofield, N.R. Helminths of sockeye salmon (Oncorhynchus nerka) from the Kvichak River system, Bristol Bay, Alaska. Fish. Bull. 1973, 71, 267-277.

29. Morado, J.F.; McFee, D. Diseases and Parasites of Juvenile Walleye Pollock, Theragra chalcogramma, from the Gulf of Alaska, 1986-1988; NOAA Technical Report National Marine Fisheries Service: Washington, DC, USA, 1996; pp. 89-103.

30. Gordeev, I.I.; Sokolov, S.G. Macroparasites of epipelagic and eurybathic fishes in the north-western Pacific. Invert. Zool. 2020, 17, 118-132. [CrossRef]

31. McClelland, G. The trouble with sealworms (Pseudoterranova decipiens) species complex (Nematoda): A review. Parasitology 2002, 124, 183-203. [CrossRef] [PubMed]

32. Klimpel, S.; Palm, H.W.; Ruckert, S.; Piatkowski, U. The life cycle of Anisakis simplex in the Norwegian Deep (northern North Sea). Parasitol. Res. 2004, 94, 1-9. [CrossRef]

33. Mehrdana, F.; Bahlool, Q.Z.M.; Skov, J.; Marana, M.H.; Sindberg, D.; Mundeling, M.; Overgaard, B.C.; Korbut, R.; Strom, S.B.; Kania, P.W.; et al. Occurrence of zoonotic nematodes Pseudoterranova decipiens, Contracaecum osculatum and Anisakis simplex in cod (Gadus morhua) from the Baltic Sea. Vet. Parasitol. 2014, 205, 581-587. [CrossRef]

34. Shamsi, S.; Suthar, J. A revised method of examining fish for infection with zoonotic nematode larvae. Int. J. Food Microbiol. 2016, 227, 13-16. [CrossRef] 